\title{
The Renaissance in Italy: a Social and Cultural History of the Rinascimento
}

Review Number: 1835

Publish date: Thursday, 24 September, 2015

Author: Guido Ruggiero

ISBN: 9780521719384

Date of Publication: 2014

Price: $£ 60.00$

Pages: 626pp.

Publisher: Cambridge University Press

Publisher url: http://www.cambridge.org/us/academic/subjects/history/european-history-after-1450/renaissance-ital and-cultural-history-rinascimento

Place of Publication: Cambridge

Reviewer: Stephen Bowd

Guido Ruggiero's new social and cultural history of Italy between 1250 and 1575 begins at the end of the world and ends at the beginning of the 'Great Social Divide'. The world that ended around 1250 was not that of the 'Second Age of Christ and the New Testament' expected by 'semiotically aroused' (1) spiritual men and women; nor was the world that emerged the 'Age of Spirit', which the apocalyptically-minded thought might presage the end of human history. Instead, an urban civilisation led by the new moneymen merchants, bankers, and investors - but drawing in lawyers and artisans, among others, gradually superseded a largely rural feudal world and challenged the dominance of the nobility and the Church.

The rise in Italy of what Ruggiero calls 'civiltà' occurred in two phases with the 'new' men and women of the 'popolo grosso' in the northern and central cities promoting a fairly flexible notion of civic 'virtù' in the first phase (to 1450) before it acquired a more aristocratic colouring in the second as social divisions widened and hardened across the peninsula. In some ways, this story of the rise of the popolo grosso and their economic and cultural success during the Rinascimento reads like an Italian version of the 'American Dream'. An 'Italian Dream' one might say. Just as the 'American Dream' emphasises a strong personal ethos and self-improvement so at the heart of Ruggiero's Italian Dream, or 'suggestion for a new paradigm' (p.14) for the Renaissance as a period and movement lies the notion of virtù, which 'stressed reason, moderation, and self-control sliding toward cunning and furbizia (cleverness that is slightly immoral, selfserving, yet effective)' (p.16). The development of this virtù was initially fuelled by the struggle to contain the destabilising violence of the 'magnates' by means of legislation such as the Ordinances of Justice in Florence, or policing bodies with legislative, judicial and administrative functions such as the Council of Ten in Venice.

The birth of the age of virtù was favoured by a number of social, political, and economic circumstances including the retreat of the pope and the emperor from Italy. In their place a 'civic morality' (p. 54) developed and prosperous cities like Siena claimed the authority to wield both spiritual and secular swords in their bid to tame murderous nobles and control jostling corporate bodies. The combined shock of the Black Death and the 'Italian Hundred Years' War' in the century after 1348 did little to hinder this 'rebirth' 
or restoration of ancient morality (as most Italians preferred to present it), or 'Rinascimento' (as Ruggiero terms it); in fact, like crises and wars in other ages, these events exacerbated some existing trends and provided new opportunities. The popolo grosso of Florence, for example, moved into lucrative new markets and trades such as wool and banking and states like Milan and Venice developed new forms of taxation, bureaucracy, or military engineering and organisation in order to defend or extend their territories. At the same time that the condottiere hired by these states fought in the field (often somewhat reluctantly) the legally-trained, like Coluccio Salutati, fought 'paper battles' (p.167) at home with appeals to liberty and republican virtues attributed to the ancient world. The 'thoroughly modern virtù' (p. 258) reflected in these and other writings was presented as ancient by a society distrustful of the new and inclined to elevate the status of the most ancient authorities even as they hungered to restore something of the first, pristine, state of the world.

Guido Ruggiero tells this story with the eloquence and mastery of the memorable turn of phrase to be expected of the author of Binding Passions: Tales of Magic, Marriage, and Power from the End of the Renaissance (1993) and Machiavelli in Love: Sex, Self, and Society in Renaissance Italy (2007). Thus, at the beginning of the book we find an imaginary pilgrim to Italy tempted by the 'sex artisans' on the streets of Venice (p. 29). Ruggiero subsequently comments on the triumph of the popolo grosso and their loss of coherent identity with some crispness: '[N]othing fails like success' (p. 76). He then remarks on the 'essential luxury' of luxury cloth (p. 137) and the 'poetry of prose' (p. 235) of Cicero's letters, which was so attractive to men like Francesco Petrarch. As for the court cultures of Italy: 'Glory was the story' (p. 282). Ruggiero's Rinascimento also offers a fresh and highly accessible narrative based on the central organising concepts of civiltà and virtù. In many respects, the argument is not original and some previous historians, for example, have explored the relationship between the idea of rebirth and apocalyptic Christian culture or even astrology in the Renaissance.(2) In addition, some readers may find the concepts of civiltà and virtù far too imprecise to be used with such confidence across three centuries and so many urban centres and courts, even though Ruggiero argues that it is precisely the flexibility of a term like virtù that made it useful (p. 113). Moreover, his use of the term Rinascimento with its echo of the romanticised Risorgimento will probably jar with some scholars, especially Italians.(3) Indeed, one of the more interesting questions asked at the round table devoted to this book at the Renaissance Society of America Conference in Berlin last March mentioned the attack by a leading Italian historian (Massimo Firpo) on non-Italian historians, especially 'AngloSaxons' for inadequate knowledge and understanding of 16th-century religious history, and for being 'selfreferential' and ignoring key Italian writings. Given this attitude, did the panel (North American, although not necessarily 'Anglo-Saxon'), judge Ruggiero's book a good riposte and something that Italians should pay serious attention to, or was it likewise for the English speakers only?(4) One member of the panel responded with ironic understatement by suggesting that the Italians were perfectly capable of writing their own history of the Renaissance if they so wished. I think this question, though, cannot be so easily dismissed and it is a great pity that the bibliography of works cited by Ruggiero is markedly Anglophone (although this probably reflects the publisher's desire to cater for a monolingual market more than authorial 'Anglo-Saxon' attitudes).

So who is this book for, and what contribution does it make to debates about the Renaissance? Ruggiero is careful to state at the outset that his book offers a 'new vision' that emphasises many of the strengths of recent scholarship. It is, he says, 'an attempt to suggest new ways of seeing the period rather than an attempt to establish a final understanding of it' and 'has been written with an eye to opening debate' and considering the place of the Renaissance in the West and modern discussions about society and culture (p. 19). In this way we may perceive a small echo of the subtitle of the seminal and seemingly inescapable work of the 19thcentury Swiss historian Jacob Burckhardt: The Civilization of the Renaissance in Italy: an Essay (1860).(5) Ruggiero's own essay (in its sense as a synonym for 'attempt') in a history of the period and movement echoes that of Burckhardt even more strongly in its emphasis on social history, and especially the history of women, sexuality, family, and customs. It is here that Ruggiero's argument works most provocatively and memorably for he shows how important civiltà and the very public virtù of discipline and self-control that characterised the first phase of the Rinascimento were for 'disciplining discourses', and especially the 
creation of the 'consensus realities' of marriage, family and honour (pp.109, 112). Ruggiero provides a guide to these 'Rinascimento family values' (p. 253) by means of the treatises on the family and marriage by Leon Battista Alberti and Francesco Barbaro and he suggests, in an explicit play on two section headings in Burckhardt's work, 'The State as a Work of Art' and 'The Development of the Individual', that individual negotiations were key in creating a 'self' that was socially recognised, a product of 'consensus realities', or in short the 'individual as a work of art' (p. 86).(6) The portrayal of the self and of the individual in art and sculpture was one expression of this negotiation between the self and public discourses, while clothing and textual representations similarly constructed or controlled Renaissance men and women as social beings. For some women, like the Bolognese noblewoman Nicolosa Sanuti, the vestimentary 'proof of virtù' was to be welcomed (Sanuti quoted at p. 365) and ego documents by men such as Petrarch or the goldsmith Benvenuto Cellini offered an elevated status for scholars, or simply an elevated sense of self. However, this construction was sometimes unsuccessful or contested. Donatello's equestrian statue of the condottiere Gattamelata ('tabby cat') gazing sternly over Padua was probably judged very successful by Venice, the employer for whom he conquered the city, but likely with much less of a glowing 'consensus' by the conquered Paduans who would later revolt against Venetian rule (p. 338). To take another example, Cassandra Fedele, like many other female writers and scholars, 'was a highly fragile work of art whose fame was contingent on a careful construction of self that teetered on a knife edge between the limited forms of fame that society was willing to recognize in women and the many evils that were associated with their renown' (p. 378).

The elegant sprezzatura (studied ease) of the aristocratic second phase of the Rinascimento represented by Baldassare Castiglione's ideal courtier and the furbizia of Niccolò Machiavelli's prince offer two sides of the same stabilising 'regime of virtù' (p. 457) for which Italians were increasingly nostalgic as Italy became dominated by foreign powers and ecclesiastical prudishness. The 'crisis of the sixteenth century' (p. 469) followed the shock of renewed widespread warfare on the peninsula with the French invasion in 1494, the shock of the new overseas discoveries (often by Italians or by men funded by Italians) that could not be presented as any sort of rebirth or renewal of the ancient world, new religious divisions in the wake of the Reformation, and new technologies such as printing with moveable type which all encouraged cultural dissonance. At the same time, the centres of civiltà like Florence and Venice lost their economic and cultural powers of attraction to northern or western European rivals as the centre of trading gravity shifted towards the Atlantic. Italians found themselves in some 'dark woods of an Italy that seemed to have lost its glory and promise' (p. 465). Ruggiero seems positively to relish these shades of the 'Dark Ages', and like a latter-day Johan Huizinga invokes the 'violent tenor of life' (eg. pp. 271, 278, 433).(7)

Ruggiero's reflections on chaos seem to reflect an underlying unease with the disciplining regime of his Rinascimento, while the 'fruits, both sweet and bitter' (p. 574) it has left for 'the increasingly global society of the twenty-first century' (p. 19) suggest an underlying and troubling modernising narrative. Thus, he detects in the work of some 'secular prophets' (p. 438) like Machiavelli, Castiglione, and Pietro Aretino a suggestion that the state should be the 'ultimate arbiter of morality' and he denounces this as 'a path that tends to lead to modern totalitarian thinkers of both left and right' (p. 457). In this way, Ruggiero again echoes Burckhardt, for the professor of Basel may have been uneasy with the individualism, secularism, and nationalism that he believed were born out of the Renaissance and shaped the modern world.(8) Similarly, in a popular synoptic history of the Italian Renaissance first published in 1961 Denys Hay, a Professor of Medieval History at the University of Edinburgh, argued for the distinctiveness of the Renaissance as period and a movement, with an appreciation of the achievements of the medieval centuries and with some effort to avoid making the Renaissance the 'herald' of the modern age: 
What has the Renaissance contributed to the railway engine, the aeroplane, mass education and the ideal of popular government? We live in a world where Latin letters are remote from our present anxieties and pleasures, where even our art and architecture have left the norms set up in the sixteenth century. Beyond that, we live, for better and for worse, in one world: Africa, Asia, the Americas are daily present, politically and economically and culturally, in our Europe; as Europe is present elsewhere ... This modern world emerged out of its predecessor.(9)

This narrative can be much less nuanced, indeed positively celebratory, and it dies hard; the economist Edmund S. Phelps recently reflected on the economic success of the 19th century in this way:

What were the origins of this dynamism? It sprang from the development of a favorable culture. In nineteenth-century Britain and America, and later Germany and France, a culture of exploration, experimentation, and ultimately innovation grew out of the individualism of the Renaissance, the vitalism of the Baroque era, and the expressionism of the Romantic period.(10)

Does Ruggiero's Rinascimento reflect an ambivalence that stems from some Western crisis of confidence? (11) As Randolph Starn has observed in his bracing review of the development of the 'early modern' periodisation in modern historiography: '[P] eriodizing the past partly depends on what we think about the future.'(12) Ruggiero avoids making a sharp distinction between the 'carnival' of the Rinascimento in its first phase and the 'lent' of the second phase but his view of the Renaissance (and perhaps the future of the West) appears decidedly Lenten.(13) Take, for example, his treatment of the humanists who have until quite recently been so dear to the modernising narratives of historians. 'There were no humanists' (p. 205), Ruggiero declares, and no such thing as 'civic humanism', at least not in the first phase of the Rinascimento. (14) Petrarch's 'esoteric and elitist vision of ancient language and knowledge' (p. 225) is mentioned along with a 'dangerous closed-mindedness' (p. 243) in rejecting everything not ancient that he shared with Dante and Boccaccio. It is true, though, that the concept of civiltà which replaces these old categories in Ruggiero's scheme is most liberating here since it relieves the teacher and student from what has become a wearisome trek through fairly rigidly defined stages of humanism and dutiful nods to men who have become as devoid of life as their all'antica portrait busts. The generosity of Ruggiero's civilità also allows scholars to move beyond debates about whether the humanists should be treated simply as grammarians or whether they developed a way of living, or even a coherent philosophy.(15) Finally, his broad conception of civiltà opens up humanism and the Rinascimento more generally to the 'peoples' ('i popoli') of Italy, as Francesco Guicciardini described them.(16) The creative energy of merchants and artisans emerges in this book with a virtù-osic edge, most obviously in the work of artists who produced decorations for court festivities (pp. 296, 347-8), but more startlingly in the world of prostitutes and courtesans (pp.434-7, 476-88), and it is to be hoped that further research in this direction may be stimulated by Ruggiero's beautiful evocations. $\underline{(17)}$

Like the 'American Dream', which recently morphed into General Secretary of the Chinese Communist Party Xi Jinping's 'Chinese Dream', Ruggiero's Italian Dream was exported all over the world. However, as a number of recent studies have shown this was a global Renaissance with many points of contact and instances of interaction which complicate the idea of the cultural centre and periphery.(18) Equally, the 'decentring' or 'provincialising' of Europe can force scholars to rethink familiar models and narratives. (19) However, Ruggiero's vision is essentially diasporic with the two-way traffic of culture into and out of Italy sounded in a very minor key indeed.(20) I think that this is probably the greatest lost opportunity to reboot the Renaissance in a book which aimed to do just that and that for many people will be the most successful attempt to do so they have encountered in a very long time.

\section{Notes}

1. Richard Landes, Heaven on Earth: The Varieties of the Millennial Experience (Oxford, 2011), p. 99. 
Back to (1)

2. Eugenio Garin linked the idea of the Renaissance to the astrological cycle of planets and periodic conjunctions which were believed to affect the rise and fall of empires: Lo zodiaco della vita: la polemica sull'astrologia dal trecento al cinquecento (Bari, 1975) (Astrology in the Renaissance: The Zodiac of Life, trans. Carolyn Jackson and June Allen [London, 1983]).Back to (2)

3. Notwithstanding the recent publication of volumes in the series Il Rinascimento italiano (Angelo Colla editore) Italian scholars seem to use the terms 'Quattrocento' and 'Cinquecento' more frequently than the label 'Rinascimento'. Marco Gentile has recently remarked the latter term is considered inaccurate and pretentious by many Italian scholars: 'Guelfi, ghibellini, Rinascimento. Nota introduttiva', in idem (ed.), Guelfi e ghibellini nell'Italia del Rinascimento (Rome, 2005), pp. vii-viii. Back to (3)

4. I am grateful to Prof. Chris Black, who asked the question, for reminding me of its wording. Back to (4)

5. Jacob Burckhardt, The Civilization of the Renaissance in Italy: an Essay, trans. L. Goldscheider, 4th revd. edn. (London, 1951).Back to (5)

6. Ibid., parts 1 and 2.Back to (6)

7. Johan Huizinga, The Autumn of the Middle Ages, trans. Rodney J. Payton and Ulrich Mammitzsch (Chicago, IL, 1996), ch. 1.Back to (7)

8. Lionel Gossman, Basel in the Age of Burkhardt: A Study in Unseasonable Ideas (Chicago, IL, 2000). Back to (8)

9. Denys Hay, The Italian Renaissance in its Historical Background (Cambridge, 1966), p. 14.Back to (9)

10. Edmund S. Phelps, 'What is wrong with the West's economies?', The New York Review of Books, 13 August $2015<$ http://www.nybooks.com> [2] [accessed 27 July 2015].Back to (10)

11. See William J. Bouwsma, 'The Renaissance and the drama of Western history' in idem, A Usable Past: Essays in European Cultural History (Berkeley and Los Angeles, CA, 1990), pp. 348-65.Back to $(11)$

12. Randolph Starn, 'Review article: the early modern muddle,' Journal of Early Modern History, 6 (2002), 296-307 (at 305).Back to (12)

13. For an attack on such '[b]inary oppositions and abstracting dichotomies' see ibid., 303. Back to (13)

14. Compare Hay, Italian Renaissance, p. 8 , p. 8 n. 2.Back to (14)

15. See ibid., and Christopher S. Celenza, The Lost Italian Renaissance: Humanists, Historians, and Latin's Legacy (Baltimore, MD, 2004), ch. 2.Back to (15)

16. Francesco Guicciardini, Storia d'Italia, ed. Constantino Panigada (Bari, 1929), vol. 2, p. 245.Back to (16)

17. Compare Sandra Cavallo, Artisans of the Body in Early Modern Italy: Identities, Families and Masculinities (Manchester, 2007), and David Rosenthal, Kings of the Street: Power, Community, and Ritual in Renaissance Florence (Turnhout, 2015), esp. ch. 2. Back to (17)

18. For example, Joan-Pau Rubiés, Travel and Ethnology in the Renaissance: South India through European Eyes, 1250-1625 (Cambridge, 2000).Back to (18)

19. For example, Jack Goody, Renaissances: The One or the Many? (Cambridge, 2010).Back to (19)

20. On the ways in which 'the new world converted the old' see Simon Ditchfield, 'Catholic Reformation and renewal', The Oxford Illustrated History of the Reformation, ed. P. Marshall (Oxford, 2015), pp. $152-85$. Back to (20)

\section{Other reviews:}

$\mathrm{H}-\mathrm{Net}$

https://networks.h-net.org/node/7651/reviews/69083/mcnamara-ruggiero-renaissance-italy-social-andcultural-history [3]

Source URL:https://reviews.history.ac.uk/review/1835 


\section{Links}

[1] https://reviews.history.ac.uk/item/142086 [2] http://www.nybooks.com\&gt;

[3] https://networks.h-net.org/node/7651/reviews/69083/mcnamara-ruggiero-renaissance-italy-social-andcultural-history 